\title{
MCM-41 supported Mo/Zr mixed oxides as catalysts in liquid phase condensation of 2-methylfuran with acetone
}

\author{
Tao Li ${ }^{a}$, Soofin Cheng ${ }^{a} *$, Jyh-Fu Lee ${ }^{b}$, Ling-Yun Jang ${ }^{b}$ \\ ${ }^{a}$ Department of Chemistry, National Taiwan University, Taipei 106, Taiwan \\ ${ }^{\mathrm{b}}$ Research Division, Synchrotron Radiation Research Center, Hsinchu 300, Taiwan
}

Received 24 June 2002; received in revised form 25 September 2002; accepted 4 November 2002

\begin{abstract}
Molybdenum and zirconium mixed oxides were supported on siliceous MCM-41 mesoporous material. The resultant materials were characterized with various techniques such as X-ray diffraction (XRD), nitrogen adsorption, Transmission electron microscopy (TEM), XANES, $\mathrm{NH}_{3}$-TPD, and Diffuse reflectance infrared Fourier transform spectra (DRIFTS) of pyridine. It was found that the well-ordered channeling pores of MCM- 41 were retained with a maximum loading of $9 \mathrm{wt} . \% \mathrm{MoO}_{3}$ and $13 \mathrm{wt} . \% \mathrm{ZrO}_{2}$. The $\mathrm{ZrMo}_{2} \mathrm{O}_{8}$ crystallites appeared with an even higher loading. The materials had surface areas greater than $500 \mathrm{~m}^{2} / \mathrm{g}$ and a relatively narrow pore size distribution. $\mathrm{MoO}_{3}$ and $\mathrm{ZrO}_{2}$ were well dispersed inside the pores of MCM- 41 . The $\mathrm{Mo}(\mathrm{VI})$ was found in octahedral coordination when no $\mathrm{ZrMo}_{2} \mathrm{O}_{8}$ crystallites were detected. The $\mathrm{MoO}_{3} / \mathrm{ZrO}_{2} / \mathrm{MCM}-41$ samples contained only Lewis acid sites. Although $\mathrm{NH}_{3}$-TPD experiments indicated that its acid strength was weaker than that of Y-zeolite, the $\mathrm{MoO}_{3} / \mathrm{ZrO}_{2} / \mathrm{MCM}-41$ materials were excellent catalysts for liquid phase condensation of 2-methylfuran (MF) with acetone to form 2,2-bis(5-methylfuryl)propane (BMP).
\end{abstract}

(C) 2003 Elsevier Science B.V. All rights reserved.

Keywords: Molybdena; Zirconia; Mixed oxide; Catalyst; Acid; MCM-41; 2-Methylfuran; Acetone; Liquid phase condensation

\section{Introduction}

Due to the hazardous properties of liquid acids such as $\mathrm{HF}$ and $\mathrm{H}_{2} \mathrm{SO}_{4}$ commonly employed in the current petrochemical industry, a great effort has been focused on the development of more environmental friendly strong solid acids [1]. Sulfated metal oxides, especially sulfated zirconia, have attracted great attention in this decade because they demonstrate high catalytic activities in skeletal isomerization of alkanes at relatively low temperatures [2-4]. However, the gradual loss of sulfur during the reaction processes is its draw-

\footnotetext{
* Corresponding author. Fax: +886-2-23636359.

E-mail address: chem1031@ccms.ntu.edu.tw (S. Cheng).
}

back. Subsequent to the discovery of strong acidity on the sulfated zirconia, Hino and Arata found that zirconia loaded with tungsten oxide [5] or molybdenum oxide [6] also showed high catalytic activities for the skeletal isomerization of alkanes and benzoylation of toluene, both of which need strong acidic catalysts. These materials, if prepared properly, could achieve surface areas of around $100-200 \mathrm{~m}^{2} / \mathrm{g}$. However, the non-uniform pore size and relatively small surface area may limit their applications in catalytic reactions involving bulky molecules, such as those encountered in synthesis of pharmaceuticals and fine chemicals.

MCM-41 is the most well studied member of the M41S meso-structured silica family discovered by the researchers at Mobil [7]. It has a uniformed 
hexagonal array of mesopores and very high surface area (typically around $1000 \mathrm{~m}^{2} / \mathrm{g}$ ). This material has been shown to be an excellent support for preparing supported catalysts with superior activities and selectivities, compared to those supported on amorphous silica, alumina, or zeolites in reactions such as hydrocracking of vacuum gas oil [8], hydrogenation of aromatics [9], and liquid phase metathesis [10]. That is because the mesoporous materials facilitate the diffusion of bulky organic molecules in and out of the porous structures [11]. However, the siliceous mesoporous material itself has no acidity and low catalytic activities. Over the past 3 years, strong acid sites were introduced onto the mesoporous materials by supporting sulfated zirconia on MCM-41 [12-16]. The resultant material was found to be a strong acid catalyst and very active in $n$-butane isomerization $[12,13,15,16]$, MTBE synthesis and $n$-pentane isomerization [14]. Although zirconia loaded with tungsten oxide [5] or molybdenum oxide [6] were also reported to be strong acid catalysts, up to now, no reports concerning mesoporous materials supported on these mixed oxides were found. The aim of this study is to introduce acid function onto the mesoporous MCM-41 material by supporting Mo/Zr mixed oxide on it and to examine the catalytic activities of the resultant materials. The catalytic reaction under investigation is the liquid phase condensation of 2-methylfuran (MF) with acetone to form 2,2-bis(5-methylfuryl)propane (BMP). Furan is a well-known representative of a series of five-member unsaturated 'heteroaromatic' compounds. In this family, bisfurylalkanes are the relevant intermediates for macromolecular chemistry [17]. The derived materials have a useful range of applications, mostly for foundry cores and molds, corrosion-resistant materials, and precursors to graphitic composites and adhesives [18]. It is produced by the condensation of 2-methylfuran with acetone catalyzed by a strong acid, either Brönsted or Lewis acids $[19,20]$. Because the furan rings are highly reactive towards electrophilic aromatic substitution [21], large amounts of oligomeric products are generally formed during the reactions of furan heterocycles over zeolite catalysts such as H- $\beta$ and H-US-Y [20]. Moreover, the strong adsorption of BMP or other reaction intermediates in the zeolite pores usually leads to extensive polymerization. As a result, the zeolite pores are blocked and the catalyst deactivates readily.
Therefore, it is necessary to search for other strong acidic materials with relatively large pores catalyzing this reaction. Van Rhijn et al. [22] used sulfonic acid functionalized MCM-41 materials as catalysts for this reaction. The highest BMP yield of $82 \%$ was obtained. These results will be compared with those over Mo/Zr mixed oxide supported on MCM-41.

\section{Experimental}

\subsection{Catalyst preparation}

Pure siliceous MCM-41 was synthesized according to the method reported by Das et al. [23]. The molar ratio of the synthesis gel composition is $\mathrm{SiO}_{2}: 0.48 \mathrm{CTMA}^{+}: 0.33 \mathrm{TPA}^{+}: 0.39 \mathrm{Na}_{2} \mathrm{O}: 0.29 \mathrm{H}_{2} \mathrm{SO}_{4}$ : $110 \mathrm{H}_{2} \mathrm{O}$. A sample of Al-MCM-41 was also prepared by using sodium aluminate (Nakarai) as the $\mathrm{Al}$ source and the $\mathrm{Si} / \mathrm{Al}$ molar ratio in the synthesis gel was 33 .

The $\mathrm{MoO}_{3} / \mathrm{ZrO}_{2} / \mathrm{MCM}-41$ samples were prepared by depositing zirconium hydroxide on MCM-41, followed by impregnation to introduce molybdena. As-synthesized MCM-41 powders were dispersed in an aqueous solution of zirconyl chloride octahydrate (Riedel-deHaën, 99.5\%) under vigorous stirring. Then aqueous ammonia was added until the $\mathrm{pH}$ reached ca. 10 to precipitate zirconium hydroxide. The obtained solids were washed until the filtrate was free of $\mathrm{Cl}^{-}$ ions. After drying in air overnight at $100^{\circ} \mathrm{C}$, the solid was impregnated with desired amount of aqueous solution of ammonium heptamolybdate (Riedel-deHaën, 99\%). The dried samples were calcined in air at $560{ }^{\circ} \mathrm{C}$ for $6 \mathrm{~h}$ (heating rate at $1{ }^{\circ} \mathrm{C} / \mathrm{min}$ ) to remove the organic surfactant. The resultant samples were further calcined at higher temperatures for $3 \mathrm{~h}$ to examine the effect of calcination temperature. The same preparation procedure was used for preparing the $\mathrm{MoO}_{3} / \mathrm{ZrO}_{2} / \mathrm{SiO}_{2}$ sample, where $\mathrm{SiO}_{2}$ is a silica gel purchased from Acros. $\mathrm{MoO}_{3} / \mathrm{ZrO}_{2}$ without support was also prepared by impregnation of zirconium hydroxide, which was obtained by precipitation of zirconyl chloride octahydrate with aqueous ammonia, with ammonium heptamolybdate. After impregnation and drying, the sample was calcined at $750{ }^{\circ} \mathrm{C}$ for $3 \mathrm{~h}$ in air. Another sample $\mathrm{MoO}_{3} / \mathrm{ZrO}_{2}+\mathrm{MCM}-41$ was prepared by physically mixing the $\mathrm{MoO}_{3} / \mathrm{ZrO}_{2}$ sample with calcined MCM-41. 


\subsection{Catalyst characterization}

Powder X-ray diffraction (XRD) patterns were recorded with a Scintag X1 diffractometer using $\mathrm{Cu} \mathrm{K} \alpha$ radiation. Nitrogen adsorption-desorption isotherms were obtained at liquid nitrogen temperature with a Micromeritics ASAP 2000 apparatus. Transmission electron microscopy (TEM) was performed on a Hitachi H-7100 instrument operated at $100 \mathrm{keV}$. The elemental contents in bulk were determined by inductively coupled plasma atomic emission spectroscopy (ICP-AES, Jarrell-Ash, ICAP9000) on the $\mathrm{HF}$ and $\mathrm{H}_{2} \mathrm{O}_{2}$ dissolved samples. The X-ray adsorption spectra were taken with synchrotron radiation at the Synchrotron Radiation Research Center, Hsinchu, Taiwan. The storage ring was operated at $1.5 \mathrm{GeV}$ with about $120-200 \mathrm{~mA}$ ring current. Data were collected using total electron yield and fluorescence detection.

The temperature-programmed desorption of ammonia $\left(\mathrm{NH}_{3}-\mathrm{TPD}\right)$ was carried out on a Micromeritics AutoChem 2910 instrument. $50 \mathrm{mg}$ of dried sample was pre-treated at $500^{\circ} \mathrm{C}$ under ultra-high pure helium $(50 \mathrm{ml} / \mathrm{min})$ for $1 \mathrm{~h}$ and then cooled to $120^{\circ} \mathrm{C}$. After introducing anhydrous $\mathrm{NH}_{3}$ at $120^{\circ} \mathrm{C}$ for $0.5 \mathrm{~h}$, the sample was flushed with helium for $1 \mathrm{~h}$. TPD profile of ammonia was obtained from 120 to $800^{\circ} \mathrm{C}$ at a heating rate of $10^{\circ} \mathrm{C} / \mathrm{min}$. The desorption process was monitored by a quadruple mass spectrometer (Thermo ONIX, ProLab) connected on line through a heated capillary interface. The mass number of 16 was followed to obtain TPD profiles of $\mathrm{NH}_{3}$ because the mass intensity is relatively strong and the interference from $\mathrm{H}_{2} \mathrm{O}$ is negligible. A HY-zeolite sample $(\mathrm{Si} / \mathrm{Al}=2.7)$ provided from Asia reference catalyst (no. 25) and another of $\mathrm{Si} / \mathrm{Al}=24$ from Advchem Laboratories Inc. were used as references.

Diffuse reflectance infrared Fourier transform (DRIFT) spectra of the samples adsorbing pyridine were recorded using a BOMEM MB155 FT-IR/Raman spectrometer. The equipment was furnished with an in situ sample cell (Harrick). The sample was pre-heated at $300^{\circ} \mathrm{C}$ for $3 \mathrm{~h}$ under $10^{-6} \mathrm{mbar}$ vacuum before pyridine vapor was introduced at room temperature, followed by evacuation for $30 \mathrm{~min}$. Spectra were acquired from room temperature to $500^{\circ} \mathrm{C}$ under vacuum.

\subsection{Catalytic study}

Catalytic activities of the samples were tested in the acid-catalyzed condensation of 2-methylfuran (MF) with acetone. In a typical case, $1.8 \mathrm{~g} \mathrm{MF}$ and $3.2 \mathrm{~g}$ acetone were mixed in a three-necked glass flask with reflux set-up. After $0.18 \mathrm{~g}$ solid catalyst was added, the reaction mixture was heated at $50^{\circ} \mathrm{C}$ with stirring for $24 \mathrm{~h}$. Then the solid was separated by filtration. The liquid to which was added known amount of toluene as an internal standard, was analyzed by a gas chromatograph equipped with an Rtx-5 column and an FID detector. The BMP selectivity was calculated based on the conversion of MF instead of acetone.

\section{Results and discussion}

\subsection{Characterization of catalysts}

As-synthesized MCM-41 was used as the precursor for the preparation of supported catalysts. In contrast to the calcined samples, the as-synthesized MCM-41 with the surfactant templates still in the pores can tolerate the media encountered in the catalyst preparation procedure. Fig. 1 shows the XRD patterns of the MCM-41 samples before and after the introduction of zirconia and molybdena. All the samples preserve the ordered hexagonal structure of MCM-41, although the intensity of the diffraction peaks of MCM-41 decreases slightly after precipitation of zirconium hydroxide and impregnation with $\mathrm{MoO}_{3}$. The relatively lower diffraction peak intensity is attributed to the decrease in diffraction contrast of the lattice when the pores are filled with either the organic template or the oxides. In addition, the unit cells shrank slightly after the samples were calcined. The XRD patterns of $10 \% \mathrm{MoO}_{3} / 7 \% \mathrm{ZrO}_{2} / \mathrm{MCM}-41$ samples calcined at different temperatures were also compared (not shown). Although a slight decrease in the diffraction peak intensity can be seen with the increase of calcination temperature, all the samples retain the ordered structure of MCM-41 after calcination at $560-800{ }^{\circ} \mathrm{C}$.

Fig. 2 shows the XRD patterns of $\mathrm{MoO}_{3} / \mathrm{ZrO}_{2} /$ MCM-41 samples with similar $\mathrm{MoO}_{3}$ loadings but different $\mathrm{ZrO}_{2}$ contents. For MCM-41 loaded with molybdena only, the ordered structure of MCM-41 collapsed completely after calcination at $750{ }^{\circ} \mathrm{C}$. 


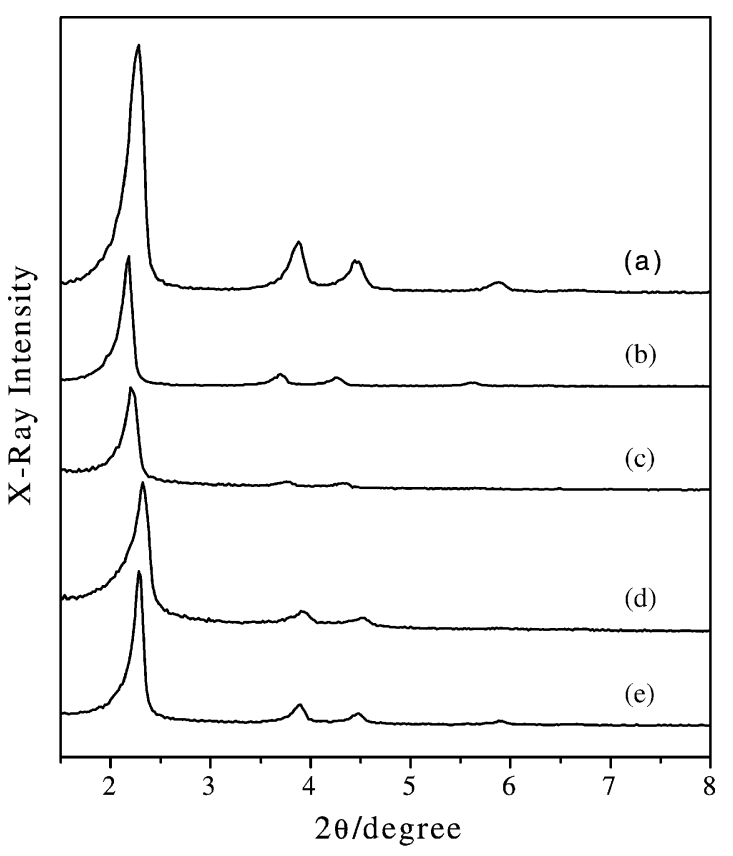

Fig. 1. XRD patterns of (a) MCM-41 (calcined at $750^{\circ} \mathrm{C}$ ); (b) as-synthesized MCM-41; (c) $9 \% \mathrm{MoO}_{3} / 13 \% \mathrm{ZrO}_{2} / \mathrm{MCM}-41$ (uncalcined); (d) $9 \% \mathrm{MoO}_{3} / 13 \% \mathrm{ZrO}_{2} / \mathrm{MCM}-41$ (calcined at $750{ }^{\circ} \mathrm{C}$ ) and (e) $14 \% \mathrm{ZrO}_{2} / \mathrm{MCM}-41$ (calcined at $750{ }^{\circ} \mathrm{C}$ ).

Other researchers have also observed similar results. Wong et al. [24] reported that MCM-41 impregnated with 6 wt. $\% \mathrm{MoO}_{3}$ suffered a drastic destruction of MCM-41. Cho et al. [25] obtained amorphous structure for Mo-MCM-41 with Mo loadings up to ca. $10 \%$. It is of great interest to notice that the ordered structure of MCM-41 was well preserved when zirconia was concomitantly introduced with molybdena. Four distinct diffraction peaks corresponding to 100,110 , 200, 210 planes of MCM-41 are visible for 8-10\% $\mathrm{MoO}_{3} / \mathrm{ZrO}_{2} / \mathrm{MCM}-41$ with $\mathrm{ZrO}_{2}$ content in the range of 4-22 wt.\%. These results imply that the $\mathrm{MoO}_{x}$ species on $\mathrm{MoO}_{3} / \mathrm{MCM}-41$ sample probably interact with the framework of MCM-41 strongly and destroy the structure. However, if MCM-41 is coated with $\mathrm{Zr}(\mathrm{OH})_{4}$ first, $\mathrm{MoO}_{x}$ species then interact with $\mathrm{ZrO}_{2}$ instead of the silica framework of MCM-41 so that the ordered structure of MCM-41 is retained. Moreover, no diffraction peaks due to $\mathrm{MoO}_{3}$ or $\mathrm{ZrO}_{2}$ crystallites were observed on all these samples. Therefore, $\mathrm{MoO}_{3}$ and $\mathrm{ZrO}_{2}$ should be well dispersed on the sur-

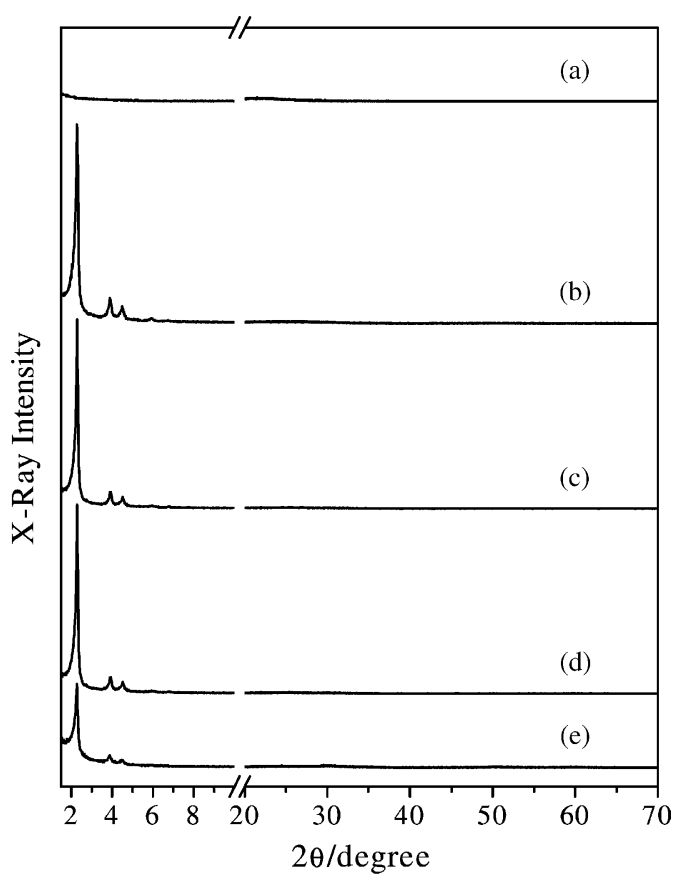

Fig. 2. XRD patterns of mixed oxides supported on MCM-41 after calcination at $750{ }^{\circ} \mathrm{C}$ for $3 \mathrm{~h}$. (a) $8 \% \mathrm{MoO}_{3}$; (b) $9 \% \mathrm{MoO}_{3} / 4 \%$ $\mathrm{ZrO}_{2}$; (c) $10 \% \mathrm{MoO}_{3} / 7 \% \mathrm{ZrO}_{2}$; (d) $9 \% \mathrm{MoO}_{3} / 13 \% \mathrm{ZrO}_{2}$ and (e) $10 \% \mathrm{MoO}_{3} / 22 \% \mathrm{ZrO}_{2}$.

face of MCM-41. The TEM photographs (not shown) also confirmed that the hexagonal meso-structure of MCM-41 was still retained and $\mathrm{MoO}_{3} / \mathrm{ZrO}_{2}$ crystals were mainly in the channels of MCM- 41.

Fig. 3 shows the XRD patterns of $\mathrm{MoO}_{3} / \mathrm{ZrO}_{2} /$ MCM-41 with similar $\mathrm{ZrO}_{2}$ contents but different $\mathrm{MoO}_{3}$ loadings. It can be seen that the patterns of samples with $\mathrm{MoO}_{3}$ loadings varying in $2-9 \mathrm{wt} . \%$ are similar to that of MCM-41 loaded with $14 \% \mathrm{ZrO}_{2}$ only. Within this range of $\mathrm{MoO}_{3}$ loading, the $\mathrm{MoO}_{3}$ seems to interact with $\mathrm{ZrO}_{2}$ and has little effect on the crystal structure of MCM-41. When the $\mathrm{MoO}_{3}$ loading is raised to $14 \mathrm{wt} . \%$, the intensity of the diffraction peaks of MCM-41 decreases drastically. Even further increase in the $\mathrm{MoO}_{3}$ loading to $17 \mathrm{wt} . \%$, caused the ordered structure of MCM-41 to collapse completely. In the mean time, the diffraction peaks corresponding to $\mathrm{ZrMo}_{2} \mathrm{O}_{8}$ phase [26] appeared. Based on the XRD results, the maximum loadings of $\mathrm{MoO}_{3}$ and $\mathrm{ZrO}_{2}$ on MCM-41 to retain the crystal structure of MCM-41 are 14 and $22 \mathrm{wt} . \%$, respectively. 


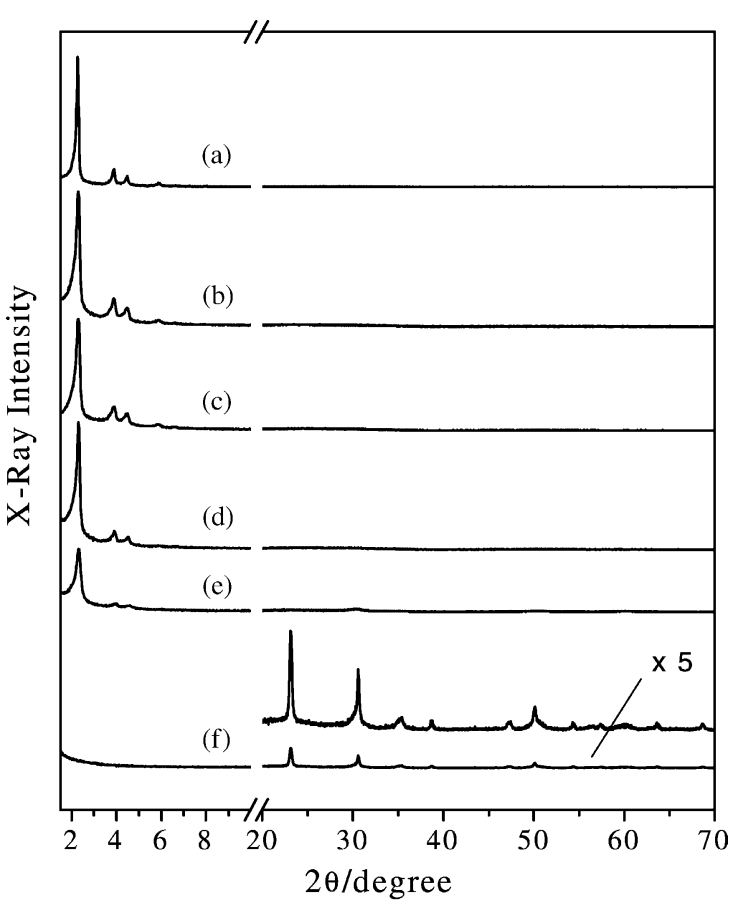

Fig. 3. XRD patterns of $\mathrm{MoO}_{3} / 14 \% \mathrm{ZrO}_{2} / \mathrm{MCM}-41$ with different $\mathrm{MoO}_{3}$ loadings after calcination at $750{ }^{\circ} \mathrm{C}$ for $3 \mathrm{~h}$ (a) $0 \%$; (b) $2 \%$; (c) $4 \%$; (d) $9 \%$; (e) $14 \%$ and (f) $17 \%$.

Iglesia and co-workers [27-29] reported that when the Mo surface density was higher than $5 \mathrm{Mo} / \mathrm{nm}^{2}$ and the calcination temperature was above $600{ }^{\circ} \mathrm{C}, \mathrm{ZrMo}_{2} \mathrm{O}_{8}$ was the predominant structure on $\mathrm{MoO}_{x} / \mathrm{ZrO}_{2}$ samples due to the strong interactions between $\mathrm{MoO}_{x}$ and $\mathrm{ZrO}_{2}$. Our $\mathrm{MoO}_{3} / \mathrm{ZrO}_{2} / \mathrm{MCM}-41$ samples calcined at $750^{\circ} \mathrm{C}$ with $\mathrm{MoO}_{3}$ and $\mathrm{ZrO}_{2}$ loadings lower than 14 and $22 \%$, respectively, do not show any diffraction peaks corresponding to $\mathrm{ZrMo}_{2} \mathrm{O}_{8}$. In these cases, the ordered structure of MCM-41 is still retained. Although $\mathrm{MoO}_{3}$ and $\mathrm{ZrO}_{2}$ have strong interactions, the well-dispersed $\mathrm{ZrO}_{2}$ on the surface of MCM-41 has a high surface area. As a result, the Mo surface density was lower than that for forming $\mathrm{ZrMo}_{2} \mathrm{O}_{8}$ structure. Above these loadings, the mesoporous structure of MCM-41 would collapses. Then, $\mathrm{MoO}_{3}$ and $\mathrm{ZrO}_{2}$ would have the opportunity to sinter together and form the $\mathrm{ZrMo}_{2} \mathrm{O}_{8}$ phase.

The physical properties measured from nitrogen adsorption-desorption isotherms of the $\mathrm{MoO}_{3} / \mathrm{ZrO}_{2} /$ MCM-41 catalysts are listed in Table 1 . The calcined parent MCM-41 sample has a BET surface area of $1085 \mathrm{~m}^{2} / \mathrm{g}$ and pore volume of $1.0 \mathrm{~cm}^{3} / \mathrm{g}$. It also has a very narrow pore size distribution centered at $27 \AA$. After molybdena and zirconia were supported on MCM-41, the surface area, pore volume and mesopore diameter decrease with the metal oxide loading. These results imply that the supported oxides should be dispersed onto the internal surfaces of the mesopores of MCM-41. BET analyses show that the supported catalysts have much larger surface areas $\left(>500 \mathrm{~m}^{2} / \mathrm{g}\right)$ than the unsupported $\mathrm{MoO}_{3} / \mathrm{ZrO}_{2}$ $\left(<100 \mathrm{~m}^{2} / \mathrm{g}\right)$. Table 1 also shows that the surface area, pore volume and mesopore diameter decrease with the increase in calcination temperature. These results are in consistence with those observed from XRD studies.

Synchrotron radiation based on X-ray absorption spectra at $\mathrm{Mo} \mathrm{L}_{3}$-edge were taken because the data provided information on the local coordination symmetry (especially tetrahedral versus octahedral) of Mo [30-35]. The $\mathrm{L}_{3}$-edge spectrum of $\mathrm{Mo}(\mathrm{VI})$ is characterized by two absorption peaks, which are assigned to the electron transition from an initial state of p-level to the excited states of predominantly d-character. For Mo in the tetrahedral field, the splitting of the d-orbitals (e and $t_{2}$ ) should be smaller than that in octahedral field $\left(\mathrm{t}_{2 \mathrm{~g}}\right.$ and $\left.\mathrm{e}_{\mathrm{g}}\right)$. Moreover, the number of orbitals is also reflected in the relative intensity of the two transitions. Mo in tetrahedral environment has two peaks in $\mathrm{L}_{3}$-edge spectra with an approximately 2:3 (e below $\mathrm{t}_{2}$ ) ratio in the peak intensity while that in octahedral coordination has a 3:2 $\left(\mathrm{t}_{2 \mathrm{~g}}\right.$ below $\left.\mathrm{e}_{\mathrm{g}}\right)$ ratio. Fig. 4 illustrates the Mo $\mathrm{L}_{3}$-edge spectra of $\mathrm{MoO}_{3} / \mathrm{ZrO}_{2} / \mathrm{MCM}-41$ samples with different $\mathrm{MoO}_{3}$ loadings, along with that of $\alpha-\mathrm{MoO}_{3}$ (octahedral $\mathrm{Mo}^{6+}$ ), $\mathrm{Na}_{2} \mathrm{MoO}_{4}$ (tetrahedral $\mathrm{Mo}^{6+}$ ) and $\mathrm{ZrMo}_{2} \mathrm{O}_{8}$ (tetrahedral $\mathrm{Mo}^{6+}$ ). It is readily seen that all the $\mathrm{MoO}_{3} / \mathrm{ZrO}_{2} / \mathrm{MCM}-41$ samples with $\mathrm{MoO}_{3}$ loading lower than $14 \mathrm{wt} . \%$ have the $\mathrm{L}_{3}$-edge spectra in agreement with Mo in octahedral coordination. However, $17 \% \quad \mathrm{MoO}_{3} / 13 \% \quad \mathrm{ZrO}_{2} / \mathrm{MCM}-41$ sample has tetrahedral $\mathrm{Mo}^{6+}$. From the XRD results, we know that $\mathrm{ZrMo}_{2} \mathrm{O}_{8}$ is formed in this sample.

The temperature-programmed desorption of ammonia $\left(\mathrm{NH}_{3}\right.$-TPD) was performed to determine the amount and the strength of acid sites on the catalysts. Fig. 5 compares the $\mathrm{NH}_{3}$-TPD profile of $\mathrm{MoO}_{3} / \mathrm{ZrO}_{2}$ supported on MCM-41 with those of siliceous MCM-41, Al-MCM-41 ( $\mathrm{Si} / \mathrm{Al}=31$ analyzed by ICP-AES), $\mathrm{MoO}_{3} / \mathrm{ZrO}_{2}$ mechanically mixed with 
Table 1

Physical properties of the $\mathrm{Mo} / \mathrm{Zr}$ mixed oxide supported on MCM-41 in comparison to those of Mo/Zr oxide supported on silica, the pristine MCM-41 and Mo/Zr mixed oxide

\begin{tabular}{|c|c|c|c|c|}
\hline Catalyst & Calcined temperature $\left({ }^{\circ} \mathrm{C}\right)$ & BET surafce area $\left(\mathrm{m}^{2} / \mathrm{g}\right)$ & BJH pore volume ${ }^{\mathrm{a}}\left(\mathrm{cm}^{3} / \mathrm{g}\right)$ & BJH pore diameter ${ }^{\mathrm{a}}(\AA)$ \\
\hline $20 \% \mathrm{MoO}_{3} / \mathrm{ZrO}_{2}$ & 750 & 77.9 & - & - \\
\hline $4 \mathrm{M} 13 \mathrm{Z} / \mathrm{SiO}_{2}$ & 750 & 181 & - & - \\
\hline MCM-41 & 560 & 1085 & 1.0 & 26.8 \\
\hline Al-MCM-41 & 560 & 1012 & 0.97 & 25.9 \\
\hline $8 \mathrm{M} 0 \mathrm{Z} / \mathrm{M} 41^{\mathrm{b}}$ & 750 & 21.6 & - & - \\
\hline 9M4Z/M41 & 750 & 758 & 0.61 & 24.5 \\
\hline 10M7Z/M41 & 750 & 708 & 0.53 & 24.8 \\
\hline 9M13Z/M41 & 750 & 624 & 0.59 & 24.8 \\
\hline 10M22Z/M41 & 750 & 503 & 0.53 & 24.2 \\
\hline 0M14Z/M41 & 750 & 846 & 0.80 & 26.6 \\
\hline 2M14Z/M41 & 750 & 718 & 0.70 & 25.5 \\
\hline 4M13Z/M41 & 750 & 694 & 0.67 & 25.3 \\
\hline 14M13Z/M41 & 750 & 463 & 0.43 & 23.8 \\
\hline 17M13Z/M41 & 750 & 58.4 & - & - \\
\hline \multirow[t]{5}{*}{ 10M7Z/M41 } & 560 & 921 & 0.73 & 25.9 \\
\hline & 650 & 756 & 0.61 & 25.9 \\
\hline & 700 & 743 & 0.59 & 25.5 \\
\hline & 750 & 708 & 0.53 & 24.8 \\
\hline & 800 & 666 & 0.47 & 22.5 \\
\hline $\mathrm{HY}(\mathrm{Si} / \mathrm{Al}=2.7)$ & - & 692 & - & - \\
\hline $\mathrm{HY}(\mathrm{Si} / \mathrm{Al}=24)$ & - & 710 & - & - \\
\hline
\end{tabular}

${ }^{a}$ Data from $\mathrm{N}_{2}$ desorption isotherm.

${ }^{\mathrm{b}}$ The MCM-41 supported catalysts were denoted as $x \mathrm{M} y \mathrm{Z} / \mathrm{M} 41$, where $x$ and $y$ are the wt.\% loading; $\mathrm{M}$ and $\mathrm{Z}$ represent $\mathrm{MoO}_{3}$ and $\mathrm{ZrO}_{2}$, respectively, and M41 is MCM-41.

MCM-41, and $\mathrm{MoO}_{3} / \mathrm{ZrO}_{2}$ supported on silica gel. The $\mathrm{MoO}_{3}$ and $\mathrm{ZrO}_{2}$ contents in the three supported samples were similar, $4 \% \mathrm{MoO}_{3}$ and $13-17 \% \mathrm{ZrO}_{2}$. Siliceous MCM-41 shows no desorption peak (profile a), indicating that it has no acidity. The $\mathrm{MoO}_{3} / \mathrm{ZrO}_{2}$ mechanically mixed with MCM-41 shows a very weak desorption peak maximized around $230{ }^{\circ} \mathrm{C}$ (profile b), while that supported on MCM-41 has a strong desorption peak with the maximum at $203{ }^{\circ} \mathrm{C}$ (profile c). The $\mathrm{MoO}_{3} / \mathrm{ZrO}_{2}$ supported on silica gel (profile d) also exhibits a strong desorption peak at ca. $218^{\circ} \mathrm{C}$, but the peak intensity is weaker than that of MCM-41. Al-MCM-41 has a broad desorption peak centered at ca. $260{ }^{\circ} \mathrm{C}$ (profile b), and the peak intensity is weaker than that of supported $\mathrm{MoO}_{3} / \mathrm{ZrO}_{2}$.

The TPD profiles of $\mathrm{HY}$-zeolites with $\mathrm{Si} / \mathrm{Al}$ atomic ratio of 24 and 2.7 are also shown in Fig. 5 as references. The one with a high $\mathrm{Al}$ content $(\mathrm{Si} / \mathrm{Al}=$ 2.7) has two huge desorption peaks at ca. 200 and $350^{\circ} \mathrm{C}$, corresponding to sites of weak and strong acidities, respectively. It implies that this sample has huge amounts of acid sites, and the amount of weak acid sites is greater than that of the strong ones. On the other hand, the HY-zeolite with low Al content $(\mathrm{Si} / \mathrm{Al}=24)$ has more sites of strong acidity, although its acid amount is relatively low. In comparison, the supported $\mathrm{MoO}_{3} / \mathrm{ZrO}_{2}$ samples and Al-MCM-41 have most of their acid sites in the weak acidity region. The results also demonstrate that $\mathrm{MoO}_{3} / \mathrm{ZrO}_{2}$ supported on either MCM-41 or silica gel contains much more acid sites than the unsupported sample or the physical mixture. These results accompanying with the BET results in Table 1 suggest that supporting $\mathrm{MoO}_{3} / \mathrm{ZrO}_{2}$ on MCM-41 can form mixed oxide of high dispersion and generate a large amount of acid sites with relatively weak acid strength. Moreover, the acid strength is close to that of Al-MCM-41 and silica supported sample.

Fig. 6 compares the $\mathrm{NH}_{3}$-TPD profiles of MCM-41 supported $\mathrm{MoO}_{3} / \mathrm{ZrO}_{2}$ with nearly the same $\mathrm{ZrO}_{2}$ content but different $\mathrm{MoO}_{3}$ loadings. For the $14 \%$ $\mathrm{ZrO}_{2} / \mathrm{MCM}-41$ sample without $\mathrm{MoO}_{3}$, only a small 


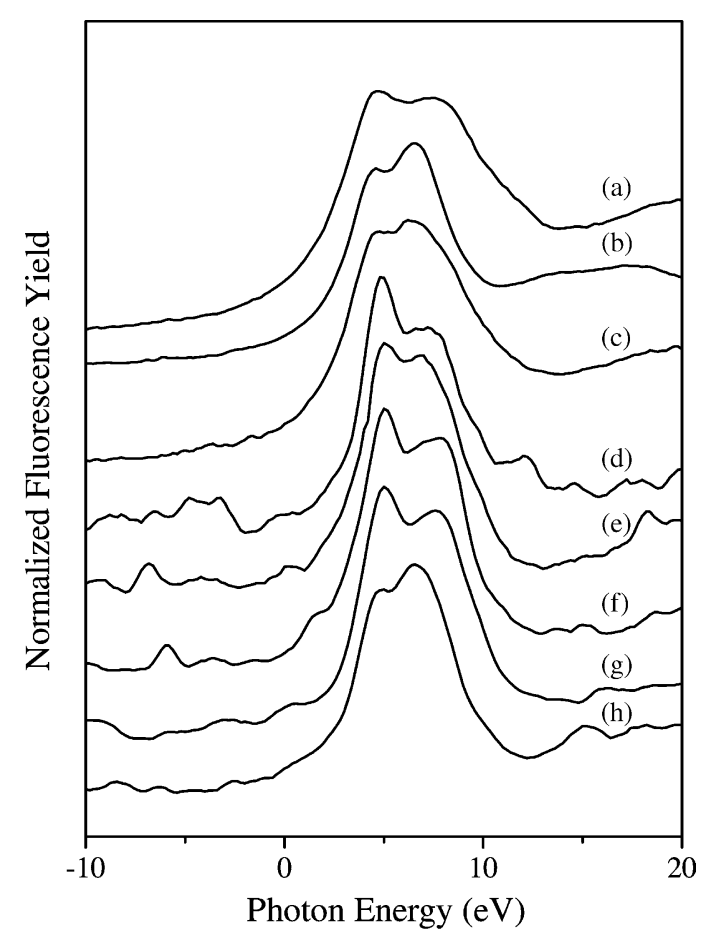

Fig. 4. XANES of Mo- $\mathrm{L}_{3}$-edge of (a) $\alpha-\mathrm{MoO}_{3}$; (b) $\mathrm{Na}_{2} \mathrm{MoO}_{4}$; (c) $\mathrm{ZrMo}_{2} \mathrm{O}_{8}$, and $\mathrm{MoO}_{3} / 14 \% \mathrm{ZrO}_{2} / \mathrm{MCM}-41$ with different $\mathrm{MoO}_{3}$ loadings after calcination at $750{ }^{\circ} \mathrm{C}$ for $3 \mathrm{~h}$ (d) $2 \%$; (e) $4 \%$; (f) 9\%; (g) $14 \%$ and (h) $17 \%$.

desorption peak can be seen (profile a). This suggests that supporting $\mathrm{ZrO}_{2}$ onto MCM-41 can only generate a small amount of weak acid sites. When both $\mathrm{MoO}_{3}$ and $\mathrm{ZrO}_{2}$ were supported on MCM-41, the amount of acid sites increased drastically, while the acid strength does not change significantly. Especially when the $\mathrm{MoO}_{3}$ loading is increased from 4 to $9 \%$, the TPD profiles show an additional desorption shoulder appearing at $244^{\circ} \mathrm{C}$ other than the main peak at $206^{\circ} \mathrm{C}$. It implies that both the amount of acid sites and the acid strength increase with the $\mathrm{MoO}_{3}$ loading. However, when the $\mathrm{MoO}_{3}$ loading is increased further to $17 \%$, only one desorption peak at $205^{\circ} \mathrm{C}$ is seen, and the peak area is lower than that containing $4 \%$ $\mathrm{MoO}_{3}$. As described above, the $17 \% \mathrm{MoO}_{3}$ sample loses the mesoporous structure of MCM-41 and the predominant species is found to be $\mathrm{ZrMo}_{2} \mathrm{O}_{8}$. Furthermore, this sample has a very low BET surface area. These results imply that $\mathrm{ZrMo}_{2} \mathrm{O}_{8}$ probably has little contribution to the acidity.

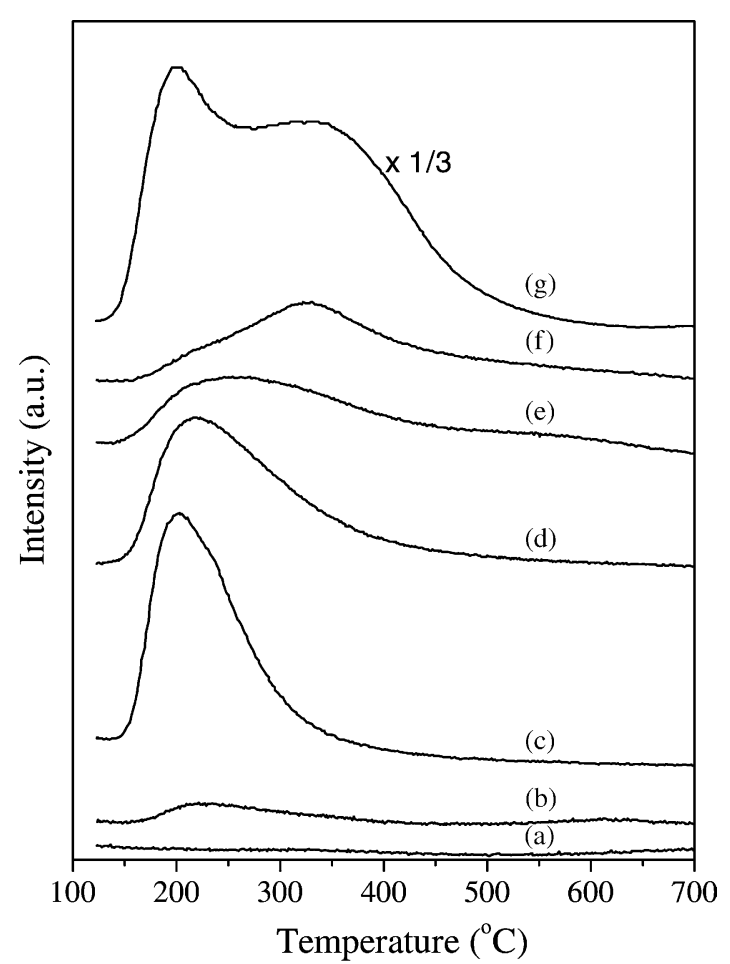

Fig. 5. $\mathrm{NH}_{3}$-TPD profiles of (a) Si-MCM-41; (b) $4 \% \mathrm{MoO}_{3} / 17 \%$ $\mathrm{ZrO}_{2}+\mathrm{MCM}-41$ (mechanically mixed); (c) $4 \% \quad \mathrm{MoO}_{3} / 13 \%$ $\mathrm{ZrO}_{2} / \mathrm{MCM}-41$; (d) $4 \% \mathrm{MoO}_{3} / 13 \% \mathrm{ZrO}_{2} / \mathrm{SiO}_{2}$; (e) Al-MCM-41 $(\mathrm{Si} / \mathrm{Al}=31)$; (f) $\mathrm{HY}(\mathrm{Si} / \mathrm{Al}=24)$ and $(\mathrm{g}) \mathrm{HY}(\mathrm{Si} / \mathrm{Al}=2.7)$.

In order to examine the effect of surface adsorbed water on acidity, the $4 \% \mathrm{MoO}_{3} / 13 \% \mathrm{ZrO}_{2} / \mathrm{MCM}-41$ sample was pre-treated with water vapor at $50{ }^{\circ} \mathrm{C}$ for $1 \mathrm{~h}$, followed by $\mathrm{NH}_{3}$-TPD experiment from 50 to $700^{\circ} \mathrm{C}$. Fig. 6(e) shows that the acidity of the sample is basically unaffected by adsorbing water on the surface. The new huge peak that appeared at ca. $100^{\circ} \mathrm{C}$ is attributed to the physically adsorbed ammonia.

The DRIFT spectra of pyridine adsorbed on $\mathrm{MoO}_{3} / \mathrm{ZrO}_{2} / \mathrm{MCM}-41$ were taken to distinguish the Brönsted and Lewis acid nature of the acid sites. Fig. 7 shows the DRIFT spectra of $9 \% \mathrm{MoO}_{3} / 13 \%$ $\mathrm{ZrO}_{2} / \mathrm{MCM}-41$ after adsorption of pyridine and desorption at various temperatures. It can be seen that only Lewis acid sites, showing the bands at 1450, 1487 and $1609 \mathrm{~cm}^{-1}$, are present on the sample. That is similar to the acid character observed on molybdena loaded zirconia [6]. Two peaks corresponding to H-bonded pyridine appearing at 1446 and $1597 \mathrm{~cm}^{-1}$ 


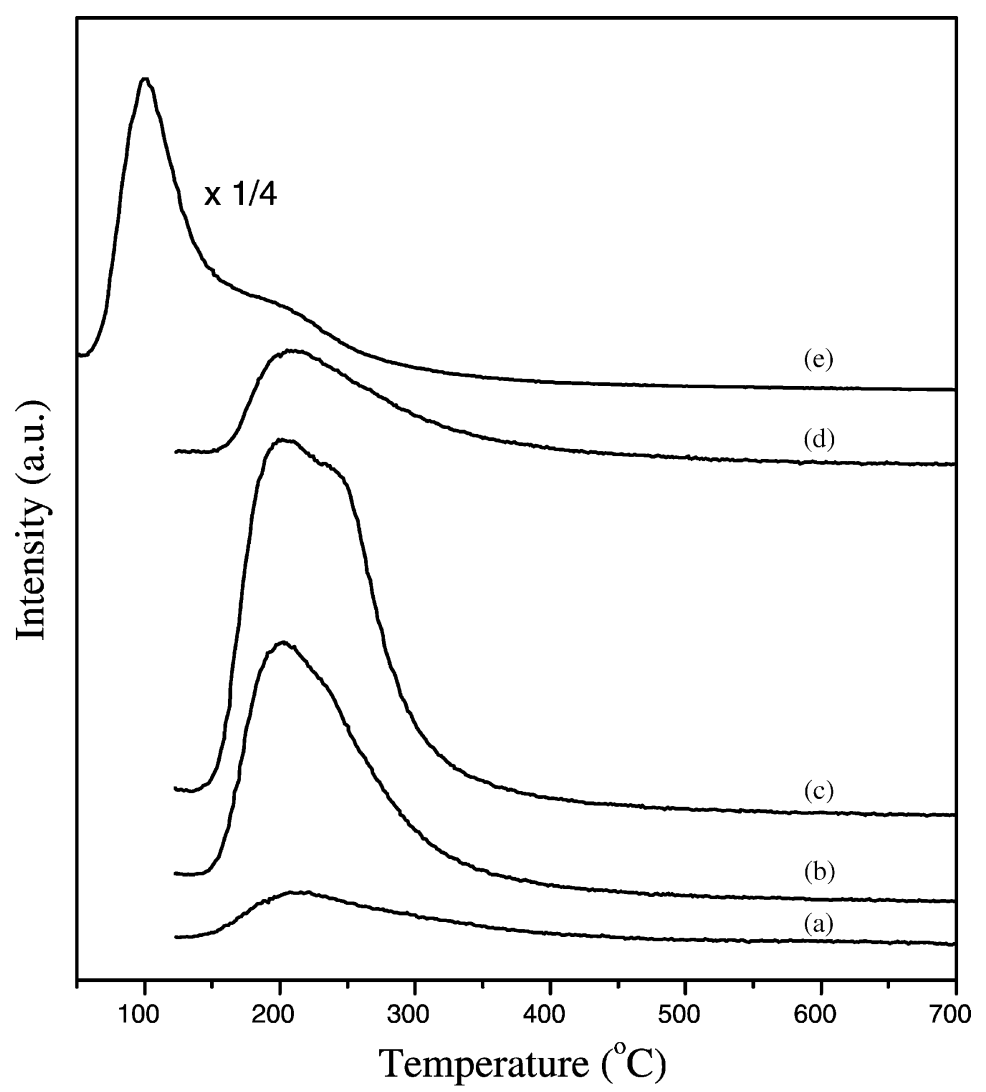

Fig. 6. $\mathrm{NH}_{3}$-TPD profiles of (a) $14 \% \mathrm{ZrO}_{2} / \mathrm{MCM}-41$; (b) $4 \% \mathrm{MoO}_{3} / 13 \% \mathrm{ZrO}_{2} / \mathrm{MCM}-41$; (c) $9 \% \mathrm{MoO}_{3} / 13 \% \mathrm{ZrO}_{2} / \mathrm{MCM}-41$; (d) $17 \%$ $\mathrm{MoO}_{3} / 13 \% \mathrm{ZrO}_{2} / \mathrm{MCM}-41$ calcined at $750{ }^{\circ} \mathrm{C}$ for $3 \mathrm{~h}$ and (e) sample (b) after exposing to moisture.

disappear after heating to $200{ }^{\circ} \mathrm{C}$. No Brönsted acid sites (characteristic at ca. $1550 \mathrm{~cm}^{-1}$ ) are observed $[14,36]$. With the increase in desorption temperature, the intensity of the characteristic peaks of Lewis acid sites decreases. The preservation of the pyridine peaks up to ca. $400{ }^{\circ} \mathrm{C}$ implies that the strength of Lewis acid sites on $\mathrm{MoO}_{3} / \mathrm{ZrO}_{2} / \mathrm{MCM}-41$ catalyst is not very weak. These results further suggest that $\mathrm{ZrO}_{2}$ as well dispersed particles probably forms a thin layer on the surface of MCM-41, and $\mathrm{MoO}_{3}$ is coated on $\mathrm{ZrO}_{2}$ and has little interaction with the silica wall.

\subsection{Catalytic studies}

The catalytic properties of MCM-41 supported $\mathrm{MoO}_{3} / \mathrm{ZrO}_{2}$ were investigated in the condensation of 2-methylfuran (MF) with acetone to synthesize 2,2-bis(5-methylfuryl) propane (BMP). Table 2 com-
Table 2

Condensation of 2-methylfuran with acetone over different catalysts $^{\mathrm{a}}$

\begin{tabular}{lcc}
\hline Catalyst & $\begin{array}{c}\text { Conversion } \\
\text { of } \mathrm{MF}(\%)\end{array}$ & $\begin{array}{l}\text { Selectivity } \\
\text { to BMP (\%) }\end{array}$ \\
\hline Blank & 0 & - \\
$\mathrm{Si}-\mathrm{MCM}-41$ & 0 & - \\
$4 \% \mathrm{MoO}_{3} / 17 \% \mathrm{ZrO}_{2}+\mathrm{MCM}^{-41} 1^{\mathrm{b}, \mathrm{c}}$ & 26 & 95 \\
$4 \% \mathrm{MoO}_{3} / 13 \% \mathrm{ZrO}_{2} / \mathrm{MCM}^{\mathrm{b}} 41^{\mathrm{b}}$ & 77 & 96 \\
$4 \% \mathrm{MoO}_{3} / 13 \% \mathrm{ZrO}_{2} / \mathrm{SiO}_{2}{ }^{\mathrm{b}}$ & $44^{\mathrm{d}}$ & 95 \\
$\mathrm{Al}-\mathrm{MCM}-41(\mathrm{Si} / \mathrm{Al}=31)$ & 18 & 85 \\
$\mathrm{HY}(\mathrm{Si} / \mathrm{Al}=24)$ & 52 & 94 \\
$\mathrm{HY}(\mathrm{Si} / \mathrm{Al}=2.7)$ & $8^{\mathrm{d}}$ & 93
\end{tabular}

${ }^{\mathrm{a}}$ Reaction conditions: MF $1.8 \mathrm{~g}$, acetone $3.2 \mathrm{~g}$ (molar ratio $=$ $1: 2.5$ ), catalyst $0.18 \mathrm{~g}$, reaction temperature $50^{\circ} \mathrm{C}$, reaction time $24 \mathrm{~h}$.

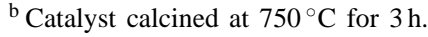

${ }^{\mathrm{c}}$ Mechanical mixture of $20 \% \mathrm{MoO}_{3} / \mathrm{ZrO}_{2}$ and MCM- 41 .

${ }^{\mathrm{d}}$ Aldol condensation of acetone was observed. 


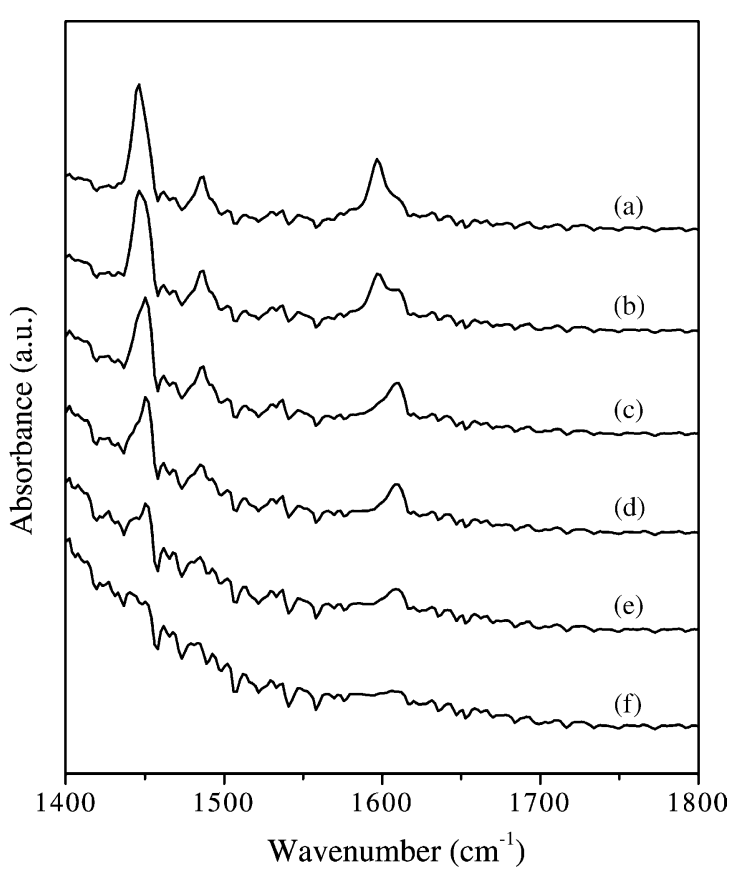

Fig. 7. In situ DRIFT spectra of pyridine adsorbed on $9 \%$ $\mathrm{MoO}_{3} / 13 \% \mathrm{ZrO}_{2} / \mathrm{MCM}-41$ calcined at $750^{\circ} \mathrm{C}$. Spectra recorded after evacuation at (a) $25^{\circ} \mathrm{C}$; (b) $100{ }^{\circ} \mathrm{C}$; (c) $200{ }^{\circ} \mathrm{C}$; (d) $300^{\circ} \mathrm{C}$; (e) $400{ }^{\circ} \mathrm{C}$ and (f) $500^{\circ} \mathrm{C}$.

pares the results of condensation of MF with acetone over MCM-41 mesoporous silica and $\mathrm{MoO}_{3} / \mathrm{ZrO}_{2}$ loaded on different supports. In the blank test reaction without any catalyst, no reaction occurs between MF and acetone. Pure siliceous MCM-41 also cannot catalyze the reaction. The three $\mathrm{MoO}_{3} / \mathrm{ZrO}_{2}$ containing catalysts give very high selectivities to BMP (90-96\%). Among them, the catalysts prepared by impregnation gave higher MF conversion than the one prepared by physical mixing, and the one supported on MCM-41 was better than that on silica gel. These results are consistent with the acid amounts observed by $\mathrm{NH}_{3}$-TPD studies. The sample, which contains the largest amount of acid sites, gives the highest activity. Because $\mathrm{NH}_{3}$-TPD and DRIFT spectra show that these samples contain no strong acid sites, these results suggest that the condensation of 2-methylfuran with acetone does not need very strong acidity to catalyze the reaction. It is also noticeable that the MF conversion is very low over $\mathrm{HY}(\mathrm{Si} / \mathrm{Al}=2.7)$ while the catalytic activity of $\mathrm{HY}(\mathrm{Si} / \mathrm{Al}=24)$ is close to those of supported $\mathrm{MoO}_{3} / \mathrm{ZrO}_{2}$. Moreover, both the MF conversion and BMP selectivity are relatively low over Al-MCM-41 $(\mathrm{Si} / \mathrm{Al}=31)$. The extremely low catalytic activity of $\mathrm{HY}(\mathrm{Si} / \mathrm{Al}=2.7)$ is attributed to the rapid deactivation of the catalyst, although no tar is detectable. The pores of HY were probably blocked by the oligomeric products of MF or the high ordered aldol condensation products of acetone since the dimer and trimer of aldol condensation products were detected in the liquid products over this catalyst. The product analysis also shows that the relatively low selectivity observed on Al-MCM-41 is due to some MF forming dimmer through alkylation.

We also compared the effect of the MF/acetone molar ratio on the MF conversion and BMP selectivity on $10 \% \mathrm{MoO}_{3} / 7 \% \mathrm{ZrO}_{2} / \mathrm{MCM}-41$. When the stoichiometric ratio of MF/acetone (2:1) is used, the MF conversion is high (91\%), but the BMP selectivity is relatively low (87\%). When the amount of acetone is increased, the MF conversions decrease to $78-84 \%$, while the BMP selectivity increases to $96 \%$. These results are elucidated by assuming that acetone in this reaction is a reactant but can also serve as the solvent. Lack of solvent may accelerate the oligomerization of 2-methylfuran. As a result, the MF conversion is high but the BMP selectivity is low. Although addition of more acetone dilutes MF and results in lower conversion, it ultimately helps to suppress MF oligomerization. In the following studies, a relatively high acetone/MF ratio was used.

Table 3 shows the MF conversion and BMP selectivity over $10 \% \mathrm{MoO}_{3} / 7 \% \mathrm{ZrO}_{2} / \mathrm{MCM}-41$ catalyst calcined at various temperatures. The MF conversion increases with the calcination temperature from 560

Table 3

Condensation of 2-methylfuran with acetone over $10 \% \mathrm{MoO}_{3} / 7 \%$ $\mathrm{ZrO}_{2} / \mathrm{MCM}-41$ catalyst calcined at different temperatures ${ }^{\mathrm{a}}$

\begin{tabular}{lll}
\hline $\begin{array}{l}\text { Calcined } \\
\text { temperature }\left({ }^{\circ} \mathrm{C}\right)\end{array}$ & $\begin{array}{l}\text { Conversion } \\
\text { of MF }(\%)\end{array}$ & $\begin{array}{l}\text { Selectivity to } \\
\text { BMP }(\%)\end{array}$ \\
\hline 560 & 73 & 97 \\
650 & 79 & 96 \\
700 & 79 & 96 \\
750 & 84 & 96 \\
800 & 81 & 96 \\
\hline
\end{tabular}

${ }^{\mathrm{a}}$ Reaction conditions: MF $1.8 \mathrm{~g}$, acetone $3.2 \mathrm{~g}$ (molar ratio $=$ $1: 2.5$ ), catalyst $0.18 \mathrm{~g}$, reaction temperature $50^{\circ} \mathrm{C}$, reaction time $24 \mathrm{~h}$. 
Table 4

Condensation of 2-methylfuran with acetone over $\mathrm{MoO}_{3} / \mathrm{ZrO}_{2} /$ MCM-41 catalyst ${ }^{a}$ with different $\mathrm{MoO}_{3}$ loadings ${ }^{\mathrm{b}}$

\begin{tabular}{llll}
\hline $\begin{array}{l}\mathrm{MoO}_{3} \\
\text { loading (\%) }\end{array}$ & $\begin{array}{l}\mathrm{ZrO}_{2} \\
\text { loading (\%) }\end{array}$ & $\begin{array}{l}\text { Conversion } \\
\text { of MF }(\%)\end{array}$ & $\begin{array}{l}\text { Selectivity } \\
\text { to BMP (\%) }\end{array}$ \\
\hline 0 & 14 & $19^{\mathrm{c}}$ & 90 \\
2 & 14 & 54 & 96 \\
2 & 14 & $52^{\mathrm{d}}$ & 96 \\
4 & 13 & 77 & 96 \\
9 & 13 & 83 & 96 \\
14 & 13 & 80 & 95 \\
17 & 13 & 61 & 97 \\
\hline
\end{tabular}

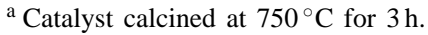

${ }^{\mathrm{b}}$ Reaction conditions: MF $1.8 \mathrm{~g}$, acetone $3.2 \mathrm{~g}$ (molar ratio $=$ $1: 2.5$ ), catalyst $0.18 \mathrm{~g}$, reaction temperature $50^{\circ} \mathrm{C}$, reaction time $24 \mathrm{~h}$.

${ }^{\mathrm{c}}$ Aldol condensation of acetone was observed.

${ }^{\mathrm{d}}$ After catalytic reaction for $24 \mathrm{~h}$, the catalyst was filtered and calcined at $700^{\circ} \mathrm{C}$ for $3 \mathrm{~h}$, then used for the second time.

to $750{ }^{\circ} \mathrm{C}$. However, the conversion decreases slightly when the calcination temperature reaches $800^{\circ} \mathrm{C}$. On the other hand, the BMP selectivity is independent of the calcination temperature and always has a value near $96 \%$. It is also interesting to find that the optimal catalytic activity of $\mathrm{MoO}_{3} / \mathrm{ZrO}_{2} / \mathrm{MCM}-41$ in the condensation of 2-methylfuran (MF) with acetone is very similar to that of sulfonic acid functionalized MCM-41, 81\% versus $82 \%$ BMP yield. The latter was reported by Van Rhijn et al. [22] based on the same catalyst weight and reaction conditions.

Tables 4 and 5 compare the catalytic results of $\mathrm{MoO}_{3} / \mathrm{ZrO}_{2} / \mathrm{MCM}-41$ with different $\mathrm{MoO}_{3}$ or $\mathrm{ZrO}_{2}$ contents. It is seen that $\mathrm{ZrO}_{2} / \mathrm{MCM}-41$ without $\mathrm{MoO}_{3}$ shows very low catalytic activity, in both conver-

Table 5

Condensation of 2-methylfuran with acetone over $\mathrm{MoO}_{3} / \mathrm{ZrO}_{2} /$ MCM-41 catalyst ${ }^{\mathrm{a}}$ with different $\mathrm{ZrO}_{2}$ loadings ${ }^{\mathrm{b}}$

\begin{tabular}{llll}
\hline $\begin{array}{l}\mathrm{MoO}_{3} \\
\text { loading (\%) }\end{array}$ & $\begin{array}{l}\mathrm{ZrO}_{2} \\
\text { loading (\%) }\end{array}$ & $\begin{array}{l}\text { Conversion } \\
\text { of MF (\%) }\end{array}$ & $\begin{array}{l}\text { Selectivity } \\
\text { to BMP (\%) }\end{array}$ \\
\hline 8 & 0 & 46 & 94 \\
9 & 4 & 80 & 95 \\
10 & 7 & 84 & 96 \\
9 & 13 & 83 & 96 \\
10 & 22 & 75 & 96 \\
\hline
\end{tabular}

\footnotetext{
${ }^{\text {a }}$ Catalyst calcined at $750{ }^{\circ} \mathrm{C}$ for $3 \mathrm{~h}$.

${ }^{\mathrm{b}}$ Reaction conditions: MF $1.8 \mathrm{~g}$, acetone $3.2 \mathrm{~g}$ (molar ratio $=$ $1: 2.5$ ), catalyst $0.18 \mathrm{~g}$, reaction temperature $50^{\circ} \mathrm{C}$, reaction time $24 \mathrm{~h}$.
}

sion and selectivity. The conversion of MF increases markedly with the increase in $\mathrm{MoO}_{3}$ loading, while the selectivity of BMP is kept constant around $95 \%$. The catalytic activity is consistent with the variation in surface area and the amount of acid sites. The 9\% $\mathrm{MoO}_{3} / 13 \% \mathrm{ZrO}_{2} / \mathrm{MCM}-41$ has the largest amount of acid sites, and it shows the highest activity. On the $17 \% \mathrm{MoO}_{3} / 13 \% \mathrm{ZrO}_{2} / \mathrm{MCM}-41$ sample, the activity decreases greatly. This sample shows very small amount of acid sites. In this case, the mesoporous structure of MCM-41 also collapses, and $\mathrm{ZrMo}_{2} \mathrm{O}_{8}$ is the predominant species. We also tested the activity of $\mathrm{ZrMo}_{2} \mathrm{O}_{8}$ sample, but it showed no catalytic activity. Over the catalysts with $8-10$ wt. $\% \mathrm{MoO}_{3}$, nearly no change in the BMP selectivity is observed when the $\mathrm{ZrO}_{2}$ content is changed. It is also noticeable that the 8 wt. $\% \mathrm{MoO}_{3} / \mathrm{MCM}-41$ catalyst without $\mathrm{ZrO}_{2}$ still has $46 \% \mathrm{MF}$ conversion, indicating that $\mathrm{MoO}_{3}$ is the main contribution to the acidity. However, the crystal structure of MCM-41 would be destroyed completely and a material of low surface area is obtained if $\mathrm{MoO}_{3}$ is loaded along (as shown in Fig. 2(a)). By introducing $\mathrm{Zr}(\mathrm{OH})_{4}$ on MCM-41 first before impregnation of $\mathrm{MoO}_{3}$, the zirconium and molybdenum mixed oxide is formed and well dispersed on MCM-41 surfaces. Compared to the catalytic activity of $\mathrm{MoO}_{3} / \mathrm{MCM}-41$ catalyst without $\mathrm{ZrO}_{2}$, the MF conversion increases markedly when $\mathrm{ZrO}_{2}$ is also present and reaches a maximum value on the catalyst with $7-13 \mathrm{wt} . \% \mathrm{ZrO}_{2}$ contents. These results also indicate that a proper ratio of $\mathrm{MoO}_{3} / \mathrm{ZrO}_{2}$ is required in order to achieve the optimal catalytic activity. From the XRD studies, 9\% $\mathrm{MoO}_{3}$ and $13 \% \mathrm{ZrO}_{2}$ were the maximum loadings on MCM-41 to preserve the hexagonal structure without the formation of $\mathrm{ZrO}_{2}, \mathrm{MoO}_{3}$ crystals or $\mathrm{ZrMo}_{2} \mathrm{O}_{8}$ species. Consistently, MCM-41 with this loading of $\mathrm{MoO}_{3} / \mathrm{ZrO}_{2}$ gave the highest catalytic activity.

The deactivation behavior of the catalyst was examined by recycling the $2 \% \mathrm{MoO}_{3} / 14 \% \mathrm{ZrO}_{2} / \mathrm{MCM}-41$ catalyst. The catalyst after $24 \mathrm{~h}$ reaction was filtered and calcined at $700^{\circ} \mathrm{C}$ for $3 \mathrm{~h}$, then used in the second time catalytic reaction. The result is shown in Table 4. The catalyst shows a minor decrease in the activity after the recycle, but the selectivity of BMP was found to still remain as high as $95-96 \%$. These results indicate that the catalyst is not deactivated significantly and is of practical use. 


\section{Conclusions}

$\mathrm{MoO}_{3} / \mathrm{ZrO}_{2}$ mixed oxides supported on siliceous MCM-41 were successfully prepared. The hexagonal ordered structure of MCM-41 was well preserved and no crystalline structure of $\mathrm{MoO}_{3}$ or $\mathrm{ZrO}_{2}$ appeared for up to $8-10 \mathrm{wt} . \% \mathrm{MoO}_{3}$ loading and $13-14 \mathrm{wt} . \% \mathrm{ZrO}_{2}$ loading. In these ranges of loading, the molybdena and zirconia are highly dispersed on the MCM-41 surface. XANES spectra showed that Mo was in octahedral coordination, and that no $\mathrm{ZrMo}_{2} \mathrm{O}_{8}$ crystals were formed. Impregnation of MCM-41 with $\mathrm{MoO}_{3}$ tends to destroy the mesoporous structure; however, the structure was well preserved when the wall of MCM-41 was first coated with $\mathrm{ZrO}_{2}$. A stronger interaction between $\mathrm{MoO}_{3}$ and $\mathrm{ZrO}_{2}$ than that of $\mathrm{MoO}_{3}$ and $\mathrm{SiO}_{2}$ was probably the reason. The $\mathrm{MoO}_{3}$ and $\mathrm{ZrO}_{2}$ loadings higher than $14 \mathrm{wt} . \%$ and $13 \%$, respectively, would lead to the formation of $\mathrm{ZrMo}_{2} \mathrm{O}_{8}$ species. The $\mathrm{MoO}_{3} / \mathrm{ZrO}_{2} / \mathrm{MCM}-41$ samples with well dispersed $\mathrm{MoO}_{3}$ and $\mathrm{ZrO}_{2}$ showed high surface areas and weak to medium acidity. Only Lewis acidity was observed on this material. The materials were highly efficient in catalyzing the condensation of 2-methylfuran and acetone with a high selectivity of 2,2-bis(5-methylfuryl)propane. MCM-41 with 9\% $\mathrm{MoO}_{3} / 13 \% \mathrm{ZrO}_{2}$ gave the highest catalytic activity. This combination was also the maximum amount of their loadings on MCM-41 with the hexagonal structure preserved and without the formation of $\mathrm{ZrO}_{2}$, $\mathrm{MoO}_{3}$ crystals or $\mathrm{ZrMo}_{2} \mathrm{O}_{8}$ species. Therefore, this loading should give the highest dispersion of Mo and Zr mixed oxide on MCM-41.

\section{Acknowledgements}

We gratefully acknowledge the financial supports from China Petroleum Corporation and the National Science Council of Taiwan.

\section{References}

[1] A. Corma, A. Martinez, Cat. Rev.-Sci. Eng. 35 (1993) 483.

[2] A. Corma, Chem. Rev. 95 (1995) 559.

[3] B.H. Davis, R.A. Keogh, R. Srinivasan, Catal. Today 20 (1994) 219.

[4] X. Song, A. Sayari, Cat. Rev.-Sci. Eng. 38 (1996) 329.

[5] M. Hino, K. Arata, J. Chem. Soc., Chem. Commun. (1988) 1259.
[6] M. Hino, K. Arata, Chem. Lett. (1989) 971.

[7] C.T. Kresge, M.E. Leonowicz, W.J. Roth, J.C. Vartuli, J.S. Beck, Nature 359 (1992) 710.

[8] A. Corma, A. Martinez, V. Martinez-Soria, J.B. Monton, J. Catal. 153 (1995) 25.

[9] A. Corma, A. Martinez, V. Martinez-Soria, J. Catal. 169 (1997) 480.

[10] T. Ookoshi, M. Onaka, Chem. Commun. (1998) 2399.

[11] S. Biz, M.L. Occeli, Cat. Rev.-Sci. Eng. 40 (1998) 329.

[12] C.-L. Chen, H.-P. Lin, S.-T. Wong, S. Cheng, C.-Y. Mou, in: Proceedings of the 3rd Seminar on Science and Technology-Catalysis, Fukuoka, Japan, 2000, p. 95.

[13] C.-L. Chen, S. Cheng, H.-P. Lin, S.-T. Wong, C.-Y. Mou, Appl. Catal. A 215 (2001) 21.

[14] Q.-H. Xia, K. Hidajat, S. Kawi, Chem. Commun. (2000) 2229.

[15] C.-L. Chen, T. Li, S. Cheng, H.-P. Lin, C.J. Bhongale, C.-Y. Mou, Microporous Mesoporous Mater. 50 (2001) 201.

[16] C.-L. Chen, T. Li, S. Cheng, H.-P. Lin, N.-P. Xu, C.-Y. Mou, Catal. Lett. 78 (2002) 223.

[17] J.E. Hall, USP 4429090 (1984); A. Gandini, EPA 0379250 (1990).

[18] M. Choura, N.M. Belgacem, A. Gandini, Macromolecules 29 (1996) 3839.

[19] I.I. Patalakh, G.D. Gankin, R.A. Karakhanov, Izv. Vyssh. Uchebn. Zaved., Khim. Khim. Tekhnol. 35 (1992) 90.

[20] A. Gandini, M.N. Belgacem, Prog. Poly. Sci. 22 (1997) 1203.

[21] M.V. Sargent, F.M. Dean, in: A.R. Katrizky, C.W. Rees (Eds.), Furans and their benzo derivative: reactivity, in Comprehensive Heterocyclic Chemistry, vol. 4, Part 3, Pergamon Press, Oxford, 1997.

[22] W.M. Van Rhijn, D.E. De Vos, B.F. Sels, W.D. Bossaert, P.A. Jacobs, Chem. Commun. (1998) 317.

[23] D. Das, C.-M. Tsai, S. Cheng, Chem. Commun. (1999) 473.

[24] S.-T. Wong, H.-P. Lin, C.-Y. Mou, Appl. Catal. A 198 (2000) 103.

[25] D.-H. Cho, T.-S. Chang, S.-K. Ryu, Y.K. Lee, Catal. Lett. 64 (2000) 227.

[26] M. Auay, M. Quarton, P. Tarte, Powder Diffr. 2 (1987) 36.

[27] A. Khodakov, J. Yang, S. Su, E. Iglesia, A.T. Bell, J. Catal. 177 (1998) 343.

[28] K.-D. Chen, S.-B. Xie, E. Iglesia, A.T. Bell, J. Catal. 189 (2000) 421.

[29] S.-B. Xie, K.-D. Chen, A.T. Bell, E. Iglesia, J. Phys. Chem. B 104 (2000) 10059.

[30] H.-C. Hu, I.E. Wachs, S.R. Bare, J. Phys. Chem. 99 (1995) 10897.

[31] H. Aritani, T. Tanka, T. Funabiki, S. Yoshida, K. Eda, N. Sotani, M. Kudo, S. Hasegawa, J. Phys. Chem. 100 (1996) 19495.

[32] W. Chun, K. Asakura, Y. Iwasawa, J. Phys. Chem. B 102 (1998) 9006.

[33] S. Bare, G. Mitchell, J.J. Maj, G.E. Vrieland, J. Gland, J. Phys. Chem. 97 (1993) 6048.

[34] S.R. Bare, Langmuir 14 (1998) 1500.

[35] S.H. Elder, F.M. Cot, Y. Su, S.M. Heald, A.M. Tyryshkin, M.K. Bowman, Y. Gao, A.G. Joly, M.L. Balmer, A.C. Kolwaite, K.A. Magrini, D.M. Blake, J. Am. Chem. Soc. 122 (2000) 5138.

[36] B.-H. Li, R.D. Gonzalez, Catal. Today 46 (1998) 55. 